\title{
Degradation Rates of Soil Chemical Fertility As Influenced by Topography in Southeastern Nigeria
}

\author{
Ezeaku, P.I* and Iwuanyanwu, F.C. \\ Department of Soil Science, University of Nigeria, Nsukka, Nigeria
}

\begin{abstract}
Understanding of soil-landscape influences on soil fertility parameters has become quite vital because of anthropogenic land mismanagement and soil degradation. Thirty soil samples were collected in 3 categories of land use (forest, grassland and cropped area - annual crops). Analytical characteristics of the samples were determined and soil chemical properties, toposequence and land use types statistically correlated using SAS. Degradation rates of selected soil chemical properties were determined. Results revealed variation in soil chemical properties within these land uses types. Amount of soil organic carbon (SOC) sequestered ranged from 18.1 to $12.5 \mathrm{~g} / \mathrm{kg}$. SOC was not influenced by land use $(p=0.252)$ but slope position $(P<0.001)$. Soil organic nitrogen levels followed similar pattern to that of SOC. CEC value was high $(>12 \mathrm{cmol} / \mathrm{kg})$ under forest, medium $(8-10 \mathrm{cmol} / \mathrm{kg})$ under annuals and low $(7 \mathrm{cmol} / \mathrm{kg})$ under grasslands. For all slope positions, highest SDR (16.1) was found under grassland soils and least value (SDR =11.0) obtained under forest soils. Low SDR implies better soil and vice versa for high SDR. Analysis showed that SDR was influenced by slope position as highest SDR (13.8) was found on foot slope and lower SDR at mid- (12.6) and up- (12.9) slopes, indicating greater management requirements for lower slope soils.
\end{abstract}

Keywords: soil fertility, degradation, land use change, management, catena

\section{Introduction}

Agriculture plays vital role in the economy of Nigeria, because it contributes to the economic and social well being of the nation through the influence on the gross domestic product (GDP), employment and foreign exchange earnings. Agricultural development is desired because the current race between increasing population and food supply is a real grim.

Most food crops are grown under rain-fed conditions and in an upland-inland continuum in Southeastern Nigeria. Increase in population has given rise to increase in land use change, resulting to soil degradation that plays major role on decline in soil fertility, nutrient balance, soil quality and productivity of the toposequence.

Land misuse and soil mismanagement, resulting from a desperate attempt by farmers to increase production of food, fibre, fuel wood and feeds for the growing population, has given rise to decline in land per capita, exercabated soil degradation with severe impacts on soil fertility and productivity (Ezeaku, 2011). Decline in soil productivity, especially in cultivated soils; lead to decline in crop yields and it is wide evident. Amana et al. (2012) have shown that reduction of crop yields are a major concern in those regions where the attainment of food security is closely related with soil degradation due to nutrient mining. This has posed a great threat to the ability of the nation to support growing rural and urban populations (Ezeaku et al., 2008). Figure1 demonstrates the nexus between land use, productivity and population.

In North southeastern Nigeria, most food crops are produced under rain-fed conditions in an uplandinland continuum. Greater proportions of farmers practice low external-input agriculture (LEIA). On the faces of demographic and environmental pressures and changes in social and political circumstances, this traditional systems are being disrupted (Udoh et al., 2002), particularly when its use is intensified and indiscriminate.

Under LEIA, the choice of land use, allocation and management may not necessarily reflect proper and adequate practices. This problem is further compounded by constraints such as financial status of the farmers, information asymmetry as regards soil properties, suitability and capabilities, etc. This situation has culminated in persistent food crisis in Nigeria as gap between population and food production continue to widen (Udoh et al., 2002). In an effort to increase food production, LEIA depends primarily on expansion of cultivated area at the expense of restorative bush fallow, thereby causing a considerable decline in the length of the cultivation cycle in slash and burn cultivation.

Cultivation over time affects the physical, chemical and biological characteristics of soils. These three characteristics are taken as measures of soil quality, which severally has been defined but centrally reflect the capability to sustain plant and animal productivity, maintain or enhance water and air quality, and promotes plant and animal health (Karlen et al., 1997; NRC, 1993). 
In densely populated areas, marginal lands and forest reserves are encroached for crop cultivation. Sustainable management practices such as reduced tillage, residue management; proper crop rotations and judicious use of fertilizers through integrated nutrient management (INM) improve soil fertility but are rarely applied by farmers. Consequently, LEIA in most cases is always not sustainable and certainly not economical.

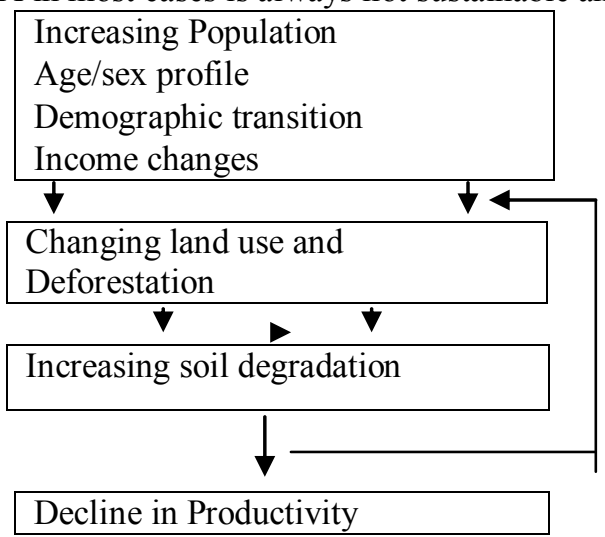

Fig. 1. Relationship between Population, Land use change and Productivity

Soil frequently occurs in a well defined and fairly regular sequence related to relief and this sequence is referred to as toposequence, which is defined as a sequence of related soils that differs, one from the other, primarily because of topography as a soil forming factor (Okunsami et al., 1997).

Table 1a. Trends in land use and productivity in the tropics - 1970 to 1999

\begin{tabular}{|ll|l|l|l|l|}
\hline \multicolumn{2}{|c|}{ Land use } & \multicolumn{2}{|c|}{ Area (Mha) } & \multicolumn{2}{l|}{ Yield $\left(\mathrm{Kgha}^{-1}\right)$} \\
\hline & & 1970 & 1999 & 1970 & 1999 \\
\hline Arable land & Permanent & & 6.80 & & \\
crops & 4.9 & 6.10 & - & - \\
Forests & 9.2 & 0.27 & 821 & 747 \\
Maize & 0.26 & & & \\
& & & & & \\
\hline
\end{tabular}

Source: FAO (1970, 1999)

It could also be described toposequence as landforms which occur as catenary sequence (physiography) and developed from the same parent materials in the same climate but under different topographical conditions owing to variation in relief and drainage.

Toposequences in North southeastern Nigeria are heterogeneous in morphology (physiography), soil type, vegetation, hydrology, and agronomic practice. Soil landscape relationships can influence the properties of soils through the summits to the foot slopes and this can be related to soil formation and erosion processes (Ezeaku and Anikwe, 2005).

Evaluation report of the changes in soil properties and productivity along a toposequence has been made elsewhere (USDA, 1996; Mojiri, et al, 2011), but the effects of catenary sequence, land use change and management on soil fertility variables under different land use types in Nsukka of north southeastern Nigeria have not received the desired research attention.

The specific objectives are to: i) quantify the amount of soil fertility properties sequestered under different land uses on a hillslope ecosystem, ii) ascertain effects of land use change, management and catenary sequence on soil properties, iii) examine soil property-management-toposequence inter-relationships, and iv) determine soil degradation rates for some measured soil properties, land use types and slope position.

The intended benefits of the study were to provide background assessment that will enhance knowledge of the soil degradation under different conditions of land use as an aid in the rehabilitation through proper management practices of the soils in a fragile soil-landscape continuum; and to further contribute to effective utilization of soil landscape ecologies so as to boost the nation's food production capacity and income growth.

\section{MATERIALS And METHOD}

\subsection{Site description}

Nigeria is located in the western part of Africa. Nsukka located in Enugu State is situated in north southeastern Nigeria by latitude $06^{0} 51^{1 \mathrm{~N}}$ and longitude $07^{0} 24^{1} \mathrm{E}$ with an elevation of $447.2 \mathrm{~m}$ above sea level (Oko-ibom and Asiegbu, 2006). The area is characterized by a humid tropical climate with wet (April- October) and dry (November -March) seasons, and a mean annual rainfall of $1750 \mathrm{~mm}$ bimodally distributed with peaks in July and September; mean annual maximum (day) and minimum (night) temperatures of $31{ }^{\circ} \mathrm{C}$ and $21{ }^{\circ} \mathrm{C}$ 
respectively (UNN Meteorological Station, 2010). The relative humidity ranges between $70 \%$ and $80 \%$ during the short harmattan period (between December and January) when temperature falls below $22^{\circ} \mathrm{C}$.

The soils of North SE Nigeria are made up of shallow and stony lithosols found on the slopes of the cuesta and often left uncultivated as typical grassland. The ferrallitic soil, also called red Earth or Acid sands, are found on the plateau, and the hydromorphic soils on the floodplains (www.google.com/Online Nigeria, 2003). The soil color matrix of the mid- and upper-slopes is deep red to brownish red and derived from sandy deposits of false bedded sandstone. They are well-drained ferallitic sandy clay loam classified at the order level as Ultisol and sub-order of Typic kandiusult (Ezeaku, 2000). Lower slopes are reddish brown to brownish black in an order of Alfisol and sub-group of Typic Kandiaquults (Soil Survey Staff, 1999).

\subsection{Geomorphology/Vegetation/Land uses}

The geomorphology of NSE Nigeria is of the highlands stretching through the undulating hills to plain lands. The vegetation is characteristically Derived savanna (Savanna-mosaic) agroecology, which represents different land uses such as forestry, cultivated areas, and grasslands in a soil-landscape system.

The vegetation on the highlands of southeastern Nigeria and stretching through its rocky promotions to link with the undulating hills is of the semitropical rainforest type. It is characteristically green and is complemented by typical grassy vegetation. The agro-ecology of Nsukka represents different land uses such as forestry, cultivated areas, and grasslands in a soil-landscape system. The green forest, especially those nearest the small populated parts, were cleared for agricultural uses since early 1990s, although a large number of these have since been left and covered with herbaceous plants and grasses as bush fallow.

During reconnaissance visits, different land uses exist along the toposequence. These include low land traditional rice farming in the valley bottom; multiple (annual) cropping (cassava, plantain, cocoyam, maize, vegetables, pepper, melon seed and beans); citrus and oil palm plantations, and fallow in the lower and upper slopes; and natural forest through the crest to lowlands. It was also discovered during preliminary visits that these different land use types are been utilized over decades in the up-down slope continuum though at subsistence level. Some parts of the area have been farmed for over 15years in a ridge-till system using both contour and up-and-down slope farming.

\subsection{Site delineation/Soil sampling}

The length of each hill to foot slope in this study was delineated following the categorization approach by Brubaker et al. (1994). Slopes on the site therefore were demarcated into different physiographic units and slope shapes; upper slope (US)(convex), middle slope (MS)(convex) and foot slope (FS)(concave) landscape position.

Two transects ( 1 and 2) were established on the physiographic units. Transect1 was $126 \mathrm{~m}$ long with 8 $\mathrm{m}$ intervals, while Transect 2 was $98 \mathrm{~m}$ long with $6 \mathrm{~m}$ intervals. These two transects constituted the sampling sites. Sampling was conducted along the catenary sequence with techniques that ensure that soil types were comparable.

\subsection{Soil sampling/Laboratory analysis}

2.4.1 Soil sampling: Three sub-samples were collected each from the upper soil layer $(0-20 \mathrm{~cm})$ and sub-surface layer $(20-40 \mathrm{~cm})$ on each of the land uses within each transect and were then mixed to obtain a homogenous sample. The depths $(0-40 \mathrm{~cm})$ were chosen because most arable and vegetable crops are surface feeders and zone where most changes are expected to occur. Auger with an internal diameter of $86 \mathrm{~mm}$ was used along the same two transects in October 2009, and again in September 2010 and September 2011. For the 3 crop years, a total of thirty samples were collected with augers at $8 \mathrm{~m}$ intervals for the $126 \mathrm{~m}$ long Transect 1 , and at $6 \mathrm{~m}$ intervals for $98 \mathrm{~m}$ long Transect 2 cutting across all land use types. Also soil core ring (of a known volume $96.6 \mathrm{~cm}^{3}$ ) samples was taken randomly from undisturbed soils at $0-10 \mathrm{~cm}$ depth for soil bulk density and soil saturated hydraulic conductivity (Ksat) determinations.

Prior to sampling, the cylinder was fitted with a dolly that protected the rim from being distorted and enabled the corer to be driven easily into the ground with a sledge hammer until it was flush with the soil surface.

At each sampling point, information on the level of management was collected from a mini survey of the farmers in the study area. The level of management was considered to be high if the field was weeded, mulched (to conserve moisture and control erosion), or pruned with application of integrated pest management (IPM) (in case of plantation trees) or if improved varieties were planted, weeded and fertilizer added (for cultivated crops); medium if improved varieties were planted, weeded but no soil conservation and fertilizer added, and poor if all the above were missing. This was based on visual observation. 
b. Laboratory analysis: Soil samples were removed from the steel collection augers and were air dried. The dried samples were gently disaggregated and mixed with a mortar and pestle. The sample was then passed through a 2-mm screen and the coarse fraction $(>2 \mathrm{~mm}$ ) separated. The $<2 \mathrm{~mm}$ soil fraction was then ground in a mill to a fine powder. All samples were stored in suitable polythene receptacles.

The analytical characteristics of the soil samples were determined in the following manner.

The percentage by weight of gravel, sand, silt, and clay (particle size diameter $<2 \mathrm{~mm}$ ) were obtained by hydrometer method (Gee and Bauder, 1986). The hydrometer method of silt and clay measurement relies on the effects of particle size on the differential vertical velocities of the particles through a water column (i.e. the sedimentation rate). Sedimentation rate is dependent upon the liquid temperature, viscosity, and the diameter and specific gravity of the falling soil particles.

Soil was dispersed into individual particles after pretreatment with hydrogen peroxide to destroy the organic matter, and addition of sodium hexametaphosphate solution to aid dispersion, then dispersed throughout a water column and allowed to settle. Hydrometer measurements quantified the amount of material remaining in suspension at specific time intervals. This was then related to the amounts of sand, silt and clay in the soil.

Soils on an undisturbed cylindrical core (volume $96.6 \mathrm{~cm}^{3}$ ) taken at field-moisture conditions were measured for bulk density on an oven-dried weight basis, and particle density with a pycnometer (Blake and Hartge, 1986).

Soil saturated hydraulic conductivity (Ksat) determination was based on method by Klute and Dickson (1986), in which an undisturbed core sample was collected and saturated over night and mounted on the retort stand after saturation to measure the rate of water drip at consistent hydraulic head of $5 \mathrm{~cm}$. When about three consecutive constant readings are obtained, it is used to calculate the hydraulic conductivity of the soil using an empirical model:

$$
\text { Ksat }=\frac{\text { Q x dz x 60 }}{\text { At DH }}
$$

Where: Ksat $=$ saturated hydraulic conductivity $(\mathrm{cm} / \mathrm{s}) ; \mathrm{Q}=$ volume of water obtained $\left(\mathrm{cm}^{3}\right) ; \mathrm{T}=$ time; $\mathrm{DH}=$ water head; $\mathrm{A}=$ Cross sectional area $(\mathrm{cm} / \mathrm{s})$, and $\mathrm{Dz}=$ height of the core sample $(\mathrm{cm})$

Soil $\mathrm{pH}$ was determined in duplicate both in distilled water and in $0.1 \mathrm{~N} \mathrm{KCl}$ solution, using a soil/liquid ratio of 1:2.5. After stirring for 30 minutes, the $\mathrm{pH}$ value was read off using a glass electrode $\mathrm{pH}$ meter (Mclean, 1982). Organic carbon (OC) was obtained by the wet dichromate acid oxidation method (Nelson and Sommers, 1982); percentage organic matter was calculated by multiplying the value for organic carbon by the "Van Bermenalen factor" of 1.724 , which is based on the assumption that soil organic matter contains $58 \%$ Carbon (Alison, 1982).

Total nitrogen was determined using the kjeldhal distillation method as described by Bremmer (1996). The ammonia from the digestion was distilled with $45 \% \mathrm{NaOH}$ into $25 \%$ boric acid and determined by titrating $0.05 \mathrm{~N} \mathrm{KCl}$.

Available phosphorus was obtained using Bray 11 bicarbonate extraction method as described by Olsen and Sommers (1982). Many extraction techniques for plant-available phosphate have been developed. The modified Olsen extractant is convenient for routine use.

Exchangeable basic cations $(\mathrm{Ca}, \mathrm{mg}, \mathrm{Na}$ and $\mathrm{K})$ were extracted in ammonium acetate $\left(\mathrm{NH}_{4} \mathrm{OA}\right)$, calcium and magnesium were determined using ethylene diamine tetraacetic acid (EDTA) titration method while potassium and sodium were determined colorimetrically using flame photometer (Rhoade, 1982a). Cation exchange capacity was determined titrimetically using $0.01 \mathrm{~N} \mathrm{NaOH}$.

\subsection{Soil Degradation Rating (SDR)}

SDR was determined as a function of SOC, soil bulk density, Ksat, soil texture, rooting depth and soil $\mathrm{pH}$. These properties were weighted as proposed by Lal (1994) with a scale of 1 to 5 (Table 1b). A weight of 1 was given when there was no limitation and five was given when the limitation was extreme. In this way, good soils had the least SDR and poor soils had the highest.

Table 1b. Rating Scheme for Soil Degradation Rating

\begin{tabular}{|lc|}
\hline Limitation & Relative weighting factor \\
\hline None & 1 \\
Slight & 2 \\
Moderate & 3 \\
Severe & 4 \\
Extreme & 5 \\
\hline
\end{tabular}

Source: Lal (1994) 
Determining the SDR of the selected soil parameters was based on the established critical limits of soil elements from various literatures (Akinrinde and Obigbesan, 2000; Enwezor et al., 1989). The critical limits of some soil properties where crop yield is $80 \%$ of the maximum yield was adopted from Aune and Lal (1997) (Table1c).

Table 1c. Critical limits of soil properties for selected crops

\begin{tabular}{|c|c|c|c|c|c|c|}
\hline \multirow[t]{2}{*}{ Soil property } & \multicolumn{4}{|c|}{ Crop } & & \\
\hline & Maize & Groundnut & cowpea & $\begin{array}{l}\text { Sweet } \\
\text { potato }\end{array}$ & Cassava & $\begin{array}{l}\text { Soya } \\
\text { bean }\end{array}$ \\
\hline Bulk density $\mathrm{Mgm}^{-3}$ & 1.5 & 1.39 & 1.39 & & 1.5 & 1.39 \\
\hline SOC $\%$ & 1.08 & & & & & \\
\hline $\mathrm{pH}$ & 5 & 5.1 & 4.7 & & & 5.1 \\
\hline Al-saturation $\%$ & 23.5 & 48.6 & 38.8 & 32.4 & 70.8 & 20.8 \\
\hline $\mathrm{P}(\mathrm{mg} / \mathrm{kg})$ & 7.6 & & & & 8.6 & 10.6 \\
\hline $\mathrm{K}^{+} \mathrm{mmol} / \mathrm{kg}$ & 0.83 & & 0.7 & & & 0.7 \\
\hline Rooting depth (cm) & 23 & 23 & 22 & 23 & 23 & 22 \\
\hline
\end{tabular}

Source: Aune and Lal (1997)

\subsection{Statistical Analysis}

Data generated was subjected to analysis using SAS (2000). Correlation analysis was carried out to determine the associations between soil fertility variables and the toposequence slopes. The least significant difference $\left(\mathrm{LSD}_{0.05}\right)$ was used to determine the differences between different land use management practices (Hoshmand, 1994) based on the several soil physical and chemical properties.

\subsection{Soil chemical properties}

\section{Results And Discussion}

The result showed that soil chemical properties varied at the three slope positions under different land uses. The results of soil $\mathrm{pH}$ showed variation from 5.4 to 6.2 with Banana/Plantain intercrop having highest mean value (6.2) and the lowest (5.4) under the grasslands. The high $\mathrm{pH}$ could be due to returning of crop residues after harvest, while low soil $\mathrm{pH}$ may be associated with leaching. Also amount and type of fertilizers normally used and the amount of leaching could contribute to low or high soil $\mathrm{pH}$. Low value of soil $\mathrm{pH}$ in the grasslands than in cultivated soils was report by Steenwerth et al. (2002).

Soil organic carbon plays an important role in water holding capacity, soil structure and overall soil health (Mojiri et al., 2011). However, the ability to sequester carbon in soil is influenced by the topography of an area in addition to the management practices, initial OC content, soil properties and land use changes (Senthil et al., 2006) )

The amounts of soil organic carbon (SOC) sequestered in different physiographic units with different land use types are presented in Table 3. The data ranged from 18.1 to $12.5 \mathrm{~g} / \mathrm{kg}$, an indication of decline downslope. High SOC at the uplands may be associated to its flatness, a characteristic that may offer some natural protection from erosion and hence SOC accumulation. Also, it may be that the movement of SOC is not related to erosion processes because soil carbon concentration is an equilibrium concentration that is more related to hill slope position and carbon inputs both from upslope and the immediate area (Li et al., 2007). They further showed that SOC may be a direct product of mineralization rates rather than being more strongly related to the material deposited and eroded due to enhanced erosion process on disturbed hill slope. Brubaker et al. (1993) made similar observation that vegetative grasses in the uplands could have provided cover that protected loss of top soil where most SOC is concentrated.

The result indicates that clay content increases exponentially with SOC. Therefore, high clay content observed on lower lands does not necessarily reflect high SOC seen on uplands. Ayanaba et al (1996) and Ayuba (2001) observed little variation in SOC due to clay content.

Table 3: Variation of mean SOC within the catenary sequence

\begin{tabular}{|lllllll|}
\hline Landscape & Mean & & & & & \\
Position & SOC & $(\text { SOC })^{-0.5}$ & SE & Mean difference & LSD $(.05)$ \\
\hline Upslope & 18.12 & $0.18 \mathrm{c}$ & 0.0052 & Foot-midslope & 0.02 & 0.01 \\
Midslope & 15.07 & $0.20 \mathrm{~b}$ & 0.0029 & Footslope-upland & 0.03 & 0.02 \\
Footslope & 12.46 & $0.26 \mathrm{a}$ & 0.0087 & Midslope-upland & 0.02 & 0.02 \\
\hline
\end{tabular}

The result (Table 3 ) showed that SOC was not influenced by management $(\mathrm{p}=0.184)$ and land use $(\mathrm{p}=0.252)$ but slope position $(\mathrm{P}<0.001)$. Lack of differences in SOC between land uses may be the type of carbon stocks available and how it is sequestered in the soil. Ne'emeth et al. (1998) found no significant differences in SOC between native vegetation, pasture and plantation land uses in Australia. The highly significant $(\mathrm{P}<0.001)$ influence by slope position could be associated to minimal erosion phenomena.

Result of soil organic nitrogen (SON) showed a range between $0.96 \mathrm{~g} . \mathrm{kg}$ and $2.46 \mathrm{~g} / \mathrm{kg}$ (Table 4). 
The SON level reflects a similar pattern to that of SOC and was corroborated by Kristensen et al. (2000). There were variations of SON within land uses, with the highest under forest, banana/plantain and cultivated annuals than others. The high $\mathrm{N}$ content under forest could be a result of nutrient recycling since the amount extracted gets returned to the soil as a litter. Mulching as management practice may have contributed to high N under Banana/Plantain land use.

When soil organic nitrogen (SON) was analyzed, it showed that it was highly influenced by slope position $(\mathrm{P}<0.05)$ and land use $(\mathrm{p}=0.006)$.

Table 4. Mean variation of soil $\mathrm{N}(\mathrm{g} / \mathrm{kg})$ among different land uses within the catenary

sequences

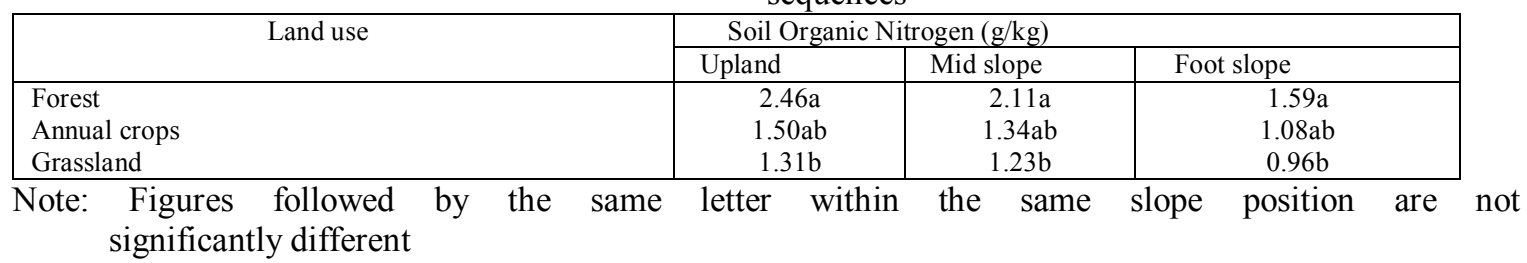

Exchangeable basic cations $(\mathrm{Ca}, \mathrm{Mg}, \mathrm{K}, \mathrm{Na})$

Calcium data ranged from 2.4 to $3.9 \mathrm{cmol} / \mathrm{kg}$. Critical values of $2.0,0.4$ and $0.20 \mathrm{Cmol} \mathrm{kg}^{-1}$ for $\mathrm{Ca}, \mathrm{Mg}$ and $\mathrm{K}$, respectively was reported by Akinrinde et al. (2000) in Nigeria. Following the level of $\mathrm{Ca}$ in the study, $\mathrm{Ca}^{2+}$ is not limiting under all land use types.

When the soil properties were regressed, the result (Table 5a) showed that $\mathrm{Ca}^{+2}$ was influenced by slope position, management level and land use, though it increased with increasing levels of management regardless of the slope position. For the same level of management, exchangeable $\mathrm{Ca}$ was highest for upslope and least for the foot slope, indicating slope position had more influence on it than management level. High levels of management on bottom lands were not significantly different from poor levels of management on the uplands and poor management on the midslopes. Upslope and midslope differences were not statistically significant. For all slope positions, the medium and high level of management were not significantly different although they both had higher $\mathrm{Ca}^{+2}$ than the footslopes implying that minimal levels of management could result in increased $\mathrm{Ca}^{+2}$ levels. No significant differences were found between footlopes with medium slopes or uplands with poor management.

Table $5 \mathrm{~b}$ shows that exchangeable $\mathrm{Ca}^{+2}$ varied with land use. $\mathrm{Ca}^{+2}$ variation was significantly $(\mathrm{P}<0.05)$ higher in grassland than cultivated areas and could be associated to high extraction by the grasses. Ayuba (2001) also reported reduced exchangeable $\mathrm{Ca}$ in grazed area.

Differences between bush fallow and the other land uses were not significant and this lack of variation may be due to fallowing land after it is completely exhausted.

No significant differences were found between Banana/Plantain intercrop and Forest, implying they had similar effect on soil $\mathrm{Ca}$. Exchangeable $\mathrm{Ca}$ under all land uses did not vary significantly from the forested areas due to high variation observed under the forest areas.

Table 5b. Comparison of Exchangeable Calcium among different land use types

\begin{tabular}{|lcl|}
\hline Pair compared & Mean difference & LSD $(0.05)$ \\
\hline Annuals-Banana/Plantain & 0.412 & $0.562 \mathrm{~ns}$ \\
Annuals-Bush fallow & 1.226 & $1.638 \mathrm{~ns}$ \\
Annuals-Grassland & 2.240 & $1.011^{*}$ \\
Annuals-Forest & 0.568 & $1.705 \mathrm{~ns}$ \\
Banana/Plantain-Bush fallow & 1.570 & $1.498 *$ \\
Banana/Plantain-Grassland & 2.508 & $0.882 *$ \\
Banana/Plantain- Forest & 1.200 & $1.98 \mathrm{~ns}$ \\
Bush fallow- grassland & 1.122 & $1.624 \mathrm{~ns}$ \\
Bush fallow-Forest & 0.626 & $2.288 \mathrm{~ns}$ \\
Banana/Plantain -Bush fallow & 2.237 & $1.549 *$ \\
Banana/Plantain-Grassland & 3.160 & $1.148 *$ \\
Banana/Plantain -Forest & 1.329 & $2.600 \mathrm{~ns}$ \\
Grassland -Forest & 1.538 & $2.811 \mathrm{~ns}$ \\
\hline
\end{tabular}

Results of exchangeable potassium $\left(\mathrm{K}^{+}\right)$varied from 0.17 to $0.42 \mathrm{cmol} / \mathrm{kg}$, corresponding to higher mean $\mathrm{K}^{+}$ values under forest and cultivated crops than grasslands (Table 6). Low $\mathrm{K}^{+}$in grasslands could be due to more extensive surface roots for moisture extraction. As grassland areas are mostly located on shallow soils used for 
grazing, $\mathrm{K}^{+}$is bound to decline with time. Leaching could also have contributed to the low $\mathrm{K}^{+}$values. Huluggale (1994) reported depleted $\mathrm{K}^{+}$values under grazed pasture in Nigeria.

Relationship between $\mathrm{K}^{+}$with land use types showed lack of effect by management and slope position but highly significantly $(\mathrm{P}<0.01)$ influenced by land use.

Table 6. Relationship between exchangeable $\mathrm{K}^{+}$with land use types

\begin{tabular}{|lc|}
\hline $\begin{array}{l}\text { Land use } \\
\left.(\mathrm{cmolkg})^{-1}\right)\end{array}$ & Exchangeable $\mathrm{K}$ \\
\hline Forest & $0.42 \mathrm{a}$ \\
Annuals & $0.34 \mathrm{a}$ \\
Grassland & $0.14 \mathrm{c}$ \\
\hline
\end{tabular}

Note: Figures followed by the same letter within the same slope position are not significantly different

Exchangeable $\mathrm{Mg}^{2+}$ data shows a variation between 0.42 and $2.23 \mathrm{cmol} / \mathrm{kg}$ (Table 7). The variation of $\mathrm{Mg}^{2+}$ content with land use type was similar at all slope positions. $\mathrm{Mg}^{2+}$ was highest in the forest followed by Banana/Plantain intercrop and annual crops. The least $\mathrm{Mg}^{2+}$ content was found under the grasslands and could be associated to leaching. High content of $\mathrm{Mg}^{2+}$ in other land uses could be attributed to litter falls. The results of low and high $\mathrm{Mg}^{2+}$ contents obtained in this study corroborates finding by Campo et al (2000) who found litter fall to account for $84 \% \mathrm{Mg}^{2+}$ in Mexico. $\mathrm{Mg}^{2+}$ was influenced by both land use and slope position and was higher at the upslope positions and low in the footslopes.

Table 7. Relationship between exchangeable $\mathrm{Mg}^{2+}$ with land use types and catena

\begin{tabular}{|l|l|l|l|}
\hline \multirow{2}{*}{ Land use } & \multicolumn{3}{|c|}{ Exchangeable $\mathrm{Mg}^{2+}(\mathrm{cmol} / \mathrm{kg})$} \\
\cline { 2 - 4 } & Upland & Mid slope & Foot slope \\
\hline Forest & $2.341 \mathrm{a}$ & $1.823 \mathrm{a}$ & $1.156 \mathrm{a}$ \\
Annual crops & $2.230 \mathrm{a}$ & $1.621 \mathrm{a}$ & $1.304 \mathrm{a}$ \\
Grassland & $1.198 \mathrm{bc}$ & $0.943 \mathrm{bc}$ & $0.418 \mathrm{bc}$ \\
\hline
\end{tabular}

Note: Figures followed by the same letter within the same slope position are not significantly different

Mean values of CEC showed lowest value $\left(6.4 \mathrm{cmol} \mathrm{kg}^{-1}\right)$ under grassland and highest value $\left(14.2 \mathrm{cmol} \mathrm{kg}^{-1}\right)$ in forest landuse (Table 8). Soil CEC has been classified as low $\left(<6 \mathrm{Cmol} \mathrm{kg}^{-1}\right)$, medium $\left(6-12 \mathrm{Cmol} \mathrm{kg}^{-1}\right)$ and high (>12 $\mathrm{Cmol} \mathrm{kg}^{-1}$ ) for some Nigerian soils (Ojanuga and Awojuola, 1981). Mean CEC is of the following decreasing order: grassland soils $(6.6 \mathrm{cmol} / \mathrm{kg})<$ Annuals $(9.8 \mathrm{cmol} / \mathrm{kg})<$ Bush fallow $(8.2 \mathrm{cmol} / \mathrm{kg})($ medium class $)<$ Banana/Plantain intercrop and Forest $(>12 \mathrm{cmol} / \mathrm{kg})$ considered high. Decrease in CEC suggests decrease in buffering capacity, and is a cause for concern as the land use types with low to medium CEC can be catalogued as unsustainable land use.

Low CEC value of tropical soils is due to dominance of kaolinitic clays in the fine earth fraction (Ojanuga et al., 1981). The CEC was not influenced by management and slope position but by land use. The CEC of a soil generally increases with soil $\mathrm{pH}$ (Spark, 1984). The low pH (5.4) obtained under grasslands could account for the low CEC of the soils. Low pH, CEC and organic matter imply decrease in biological activities, which has its own adverse effect on productivity of soils.

Table 8. Relationship between CEC with land use types

\begin{tabular}{|lc|}
\hline Land use & CEC $\left(\mathrm{cmolkg}^{-1}\right)$ \\
\hline Forest & $14.2 \mathrm{a}$ \\
Annuals & $9.8 \mathrm{a}$ \\
Grassland & $6.4 \mathrm{~b}$ \\
\hline
\end{tabular}

Note: Figures followed by the same letter within the same slope position are not significantly different

Phosphorus occurs in soils in both organic and inorganic forms. Inorganic forms are usually more important for crop nutrition (Enwezor et al., 1989). Table 9 shows the data for extractable inorganic P. Mean values of $\mathrm{P}$ were in the range of $5.92 \mathrm{mg} / \mathrm{kg}$ to $16.2 \mathrm{mg} / \mathrm{kg}$ with the least obtained in grassland soils. Forest and Banana/Plantain intercrop had highest values.

Table 8. Relationship between Exchangeable P under Different land use types

\begin{tabular}{|lcc|}
\hline Land use & Exchangeable $\mathrm{P}\left(\mathrm{mgkg}^{-1}\right)$ & Standard error \\
\hline Forest & $16.18 \mathrm{a}$ & 0.16 \\
Annuals & $9.51 \mathrm{ab}$ & 0.09 \\
Grassland & $5.92 \mathrm{c}$ & 0.19 \\
\hline
\end{tabular}


Note: Figures followed by the same letter within the same slope position are not significantly different

A critical range of 8 to $12 \mathrm{mgkg}^{-1} \mathrm{P}$ was reported for Nigerian soils (Enwezor et al., 1989). This shows that except for Forest $\left(16.2 \mathrm{mg} / \mathrm{kg}\right.$ ) and Banana/Plantain $\left(13.2 \mathrm{mgkg}^{-1}\right)$, all other land use types were P deficient. The high $\mathrm{P}$ availability, especially in Banana/Plantain intercrop soils could be attributed to higher organic materials from mulch materials used as management practice. Buerkert et al. (2000) found an increased P availability due to mulch materials in West Africa. In general, phosphorus deficiency in soils has been related to leaching by intense rainfall, high weatherability of the soils, presence of kaolinitic clay as the dominant mineral, and adsorption reaction by soil constituents (Enwezor et al., 1989).

Soil Degradation Rating

Soil degradation rating for the measured soil properties are presented in Table 9a. The mean limitation for soil texture and soil organic carbon was moderate $(\mathrm{SDR}=3.0)$ and slight for $\mathrm{pH}(\mathrm{SDR}=2.3)$ and none limiting $(\mathrm{SDR}=1.3)$ for soil bulk density eventhough it often poses extreme limitations on hill slopes.

Table 9a: Mean soil degradation rating for the measured soil properties

\begin{tabular}{|lccccc|}
\hline Soil property & Minimum & Maximum & Mean & $\begin{array}{c}\text { Standard } \\
\text { Deviation }\end{array}$ & $\begin{array}{c}\text { Standard } \\
\text { Error }\end{array}$ \\
\hline Soil texture & 1.0 & 5.0 & 2.7 & 0.41 & 0.013 \\
Bulk density & 1.0 & 5.0 & 1.3 & 0.57 & 0.022 \\
Ksat & 1.0 & 5.0 & 1.2 & 0.51 & 0.018 \\
Soil pH & 1.0 & 5.0 & 2.3 & 1.30 & 0.043 \\
SOC & 1.0 & 4.0 & 2.9 & 0.27 & 0.011 \\
SDR & 8.0 & 24.0 & 10.4 & 2.36 & 0.082 \\
\hline
\end{tabular}

Table 9b. Soil Degradation rating under land use types and toposequence

\begin{tabular}{|c|c|c|c|}
\hline \multirow[t]{2}{*}{ Land use } & \multicolumn{3}{|c|}{ Soil degradation rating (SDR) } \\
\hline & Upland & Mid slope & Foot slope Mean \\
\hline Forest & $10.6 \mathrm{a}$ & $10.4 \mathrm{a}$ & $11.9 \mathrm{a}$ \\
\hline Annual crops & $12.8 \mathrm{ab}$ & $12.6 \mathrm{ab}$ & $14.6 \mathrm{ab}$ \\
\hline Grassland & $17.8 \mathrm{~b}$ & $14.4 \mathrm{~b}$ & $16.2 b$ \\
\hline
\end{tabular}

Note: Figures followed by the same letter within the same slope position are not significantly different

The SDR values in Table $9 \mathrm{~b}$ ranged from 10.4 to 17.8. For all slope positions, the highest SDR was found under grassland soils (mean $\mathrm{SDR}=16.1$ ) and least $(\mathrm{SDR}=11.0)$ values obtained in forest. The $\mathrm{SDR}$ for banana/plantain intercrop and annual crop soils were intermediate. A low SDR implies a better soil. High SDR in grassland may be associated to a relatively long time it takes to recover the nutrients that are lost during cultivation. This could suggest the soil as of low quality. Sanchez et al. (2002) similarly found high degradation levels under grassland and attributed it to soil compaction, an increase in bulk density, low soil depth and high proportions of coarser aggregates in the top soil. . The SDR was significant $(\mathrm{P}<0.05)$ with land use and slope position but not significant with management.

Table 9c: Variation of Soil Degradation Rating with slope position

\begin{tabular}{|lc|}
\hline Slope position & Mean Soil Degradation Rating \\
\hline Up land & $12.9 \mathrm{ab}$ \\
Mid slope & $12.4 \mathrm{~b}$ \\
Foot slope & $13.8 \mathrm{a}$ \\
\hline
\end{tabular}

Note: Figures followed by the same letter within the same slope position are not significantly differen

Interaction between SDR and land use types showed a low SDR in forest and banana/plantain intercrop, which can be associated to presence of high litter fall and mulching, hence no significant difference between them irrespective of slope position. Slightly high SDR in annuals relative to forest and banana/plantain intercrop may be due to continuous cultivation and poor protection at the beginning of the rainy season and when there is minimal cover.

The relationship between SDR and slope indicated that SDR was influenced by slope position. Highest SDR was found at the foot slope followed by upslope and lowest at mid slope (Table 9c), though the SDR at the bottom slope was not significant from that of the upland slope. This lack of variation could be attributed to shallow soils on the upland and poor drainage at the foot slope, suggesting further that lower slopes become inundated during the rainy season. 


\section{Conclusion}

The study identified a significant role for topography on SOC storage in soil in addition to other determinant factors such as climate and land use changes. The results revealed that soil properties under different land use types and catenary sequences varied. The land use types were located between upland, midland and lowland physiographies. Management practices varied with land use. Soil physicochemical properties varied within the various LUTs.

The SDR was highly significant with land use and slope position but not significant with management. For all slope positions, the highest SDR was found under grassland soils and least values obtained in forest, annual crop and banana/plantain intercrop soils. A low SDR value implies a better soil and vice versa for a high SDR soil.

The relationship between SDR and slope showed that SDR was influenced by slope position with foot slope having highest SDR and lowest SDR at mid slope, suggesting greater management requirements for the former soils.

\section{Recommendation}

Careful assessment of the land resources is essential to make any change in the natural ecosystem. Encroachment on such areas by agriculture to provide more food may lead to deterioration of soil health through the rapid loss of soil fertility parameters. Appropriate legislation is important to safeguard the biodiversity of our ecosystem against deforestation and other anthropogenic activities by man in the course of meeting human needs.

No-till or reduced tillage practices should be embarked upon to increase SOM in the soil. Increase in residue return, less mixing and less soil disturbance ensures higher moisture control, reduced soil surface temperature, proliferation of root growth and bio-activity and decrease risk of soil erosion and productivity decline. Contrary will accelerate the mineralization of soil organic carbon, which in turn affects negatively the productivity potentials of the soil.

The ridge-furrow system has been suitable for soil and water conservation in structurally unsuitable soils (Lal, 1985). Since it conserves water, and also increases effective root volume on poorly drained soils and on nutrient deficient soils, it is recommended for practical application by rural farmers and agriculturist farming in the upland-inland continuum of north SE Nigeria.

\section{Acknowledgement}

The author is a Regular Associate of the Federation and Associate Scheme of the Abdus Salam International Centre for Theoretical Physics (ICTP), Trieste, Italy. I am immensely grateful to ICTP for providing Library and Computer facilities that enabled the final preparation of this work.

\section{References}

[1]. P.N. Ahn. West African soils London Oxford University Press. 1975 pp 232.

[2]. E.A. Akinrinde, and G.O. Obigbesa, . Evaluation of fertility status of selected soils for crop production in Five ecological areas of Nigeria. Proc. $26^{\text {th }}$ Ann. Conf. Soil Sci. Soc. Nig., Ibadan, Oyo State., 2000 pp279-453

[3]. F.E. Allison. Organic carbon. In: Black C.A. (ed). Methods of soil analysis part 2. American Soc. Agron. 9, 1982, 1367-1378.

[4]. S.M. Amana, O.J. Jayeoba and O.O. Agbede. Effects of land use types on soil quality in a southern Guinea savannah, Nasarawa state of Nigeria. Journal of Soil Science. vol. 22(1), 2012, 181

[5]. J.B. Aune and R. Lal . Agricultural productivity in the tropics and critical limits of properties of oxisol, ultisol and alfisol. Tropical Agric. 74, 1997, 96-103

[6]. Ayanaba, S.B. Tuckwell and D.S. Jenkinson. The effects of clearing and cropping on the organic reserves and biomass of tropical forest soils. Soil Biochem 8, 1996, 519-525

[7]. H.K. Ayuba. Livestock grazing intensities and soil deterioration in the semi-arid rangeland of Nigeria: Effects on soil chemical status. Discov. Innovate 13 (3-4), 2001, 150-155

[8]. G.R. Blake, and K.H. Hartge. Bulk density. In Methods of Soil Analysis, part 1, A. Klute (Ed.) Agron. No 9. USA Madison W.I. 1986, pp 370-373

[9]. R.H. Bray and N.T. Kurtz. Determination of total organic and availableform of phosphorus. Soil Sci. 59, 1945, 39-45

[10]. J.M. Bremmer, and C.S. Mulvaney. Total N, P. 895-926. In: Page et al (eds) Methods of Soil Analysis. Part2. $2^{\text {nd }}$ ed. Agron. Monog. 9. ASA and SSSA, Madison WI. 1982

[11]. JM. Bremmer. Nitrogen total. In: Sparks D. L. (eds). Method of soil analysis part 111. Chemical methods SSSA book series No. 5 . Am. Soc. of Agron. 1986, 1085- 1121.

[12]. SC. Brubaker, A.J. Jones, and D.T. Lewis Frank.. Soil properties associated with landscape position. Soil Sci. Soc. Amer. J. 57, $1994,235-239$

[13]. Buerket, A., A. Batiano and K. Dossa. Mechanism of residue induced cereal growth increases in W. Africa. Soil Sci. Soc. Amer. J. 64, 2000, 346-358

[14]. J. Campo, J.M. Maass, V.J. Jaramilo, and A.M. Yrizar. Ca, K and Mg cycling in a Mexican tropical dry forest ecosystem. Biogeochemistry 49(1), 2000, 21-36

[15]. Cerda. Soil aggregate stability under different Mediterranean vegetation types. Catena 32, 1998b, 73-86

[16]. O.S. Eludoyin, and C.C. Wokocha CC.. Soil dynamics under continous monocropping of maize (Zea mays) on a forest alfisol in south-western Nigeria. Asian journal of agricultural sciences. 3(2), 2011, 58-62 
[17]. W.O. Enwezor, A.C. Ohiri, E.E. Opuwaribo and E.J. Udo. Review of fertilizer use on crops in Southeastern Nigeria. Fertilizer Procurement and Distribution, Lagos, Nigeria.1989. 420pp.

[18]. P.I. Ezeaku. Methodologies for Agricultural Land Use Planning: Sustainable soil management and productivity.Published by Great AP Express Publishers Ltd, Nsukka, Nigeria. 2011, 248p

[19]. P.I. Ezeaku, and D. Alaci). Analytical situations of land degradation and sustainable management strategies in Africa. Pakistan J Agric. Soc Sci., 4, 2008, 42-52 (http://www.fspublishers.org)

[20]. P.I. Ezeaku and M.A.N. Anikwe, MAN. A model for description of water and solute movement in soil-water restrictive horizons across two landscapes in South-East Nigeria. Journal of Soil Science 171(6), 2005, 492-500

[21]. P.I.Ezeaku. Applicability of two concepts of land evaluation to the soils of southeastern Nigeria. PhD Thesis. University of Nigeria Nsukka. 2000, $271 \mathrm{p}$

[22]. FAO production year book. (1970)

[23]. FAO production year book. (1999)

[24]. FORMECU, (1998). The assessments of vegetation and land use changes in Nigeria. 1976/1978 and 1993/95. Federal Dept. of Forestry, Abuja. 30pp.

[25]. Gee, GW., Bauder, JW (1986). Particle Size Analysis. P.383-411. In: Klute,A (ed). Methods of Soil Analysis. Part 2, $2^{\text {nd }}$ ed. Agron. Monog. 9. ASA and SSSA, Madison, WI

[26]. A.E. Hertemink, , T. Veldkamp, and Z. Bai,. Land use change and soil fertility decline in tropical regions. Turkish J. of Agric. \& Forestry, 32, 2008, 195-213

[27]. R.A. Hoshmand. Experimental Research Design and Analysis. A practical approach for agricultural and natural sciences. CRC Press. 1994, 408 pp

[28]. N.R. Hullugale. Long-term effects of land clearing methods, tillage systems and cropping systems on surface soil properties of a tropical Alfisol in SW Nigeria. Soil Use Mgt 10(1, 1994, 25-30

[29]. D.L. Karlen, M.J. Mausbach, J.W. Doran, R.Q. Cline, R.F. Harris, and G.E. Schuman. Soil quality: a concept, definition and framework for evaluation. Soil Sci. Soc. Amer. J. 61, 1997, 4-10

[30]. Klute and J. Dirksen. Hydraulic conductivity and diffusivity. Laboratory methods. In: A klute (ed). Methods of soil analysis part 1 $2^{\text {nd }}$ ed. $1986,687-734$.

[31]. H.L Kristensen,., G.W. McCarty,and J.J. Meisinger. Effects of soil structure disturbance on mineralization of organic soil nitrogen. Soil Sci. Amer. J 61(1), 2001, 371-378

[32]. R. Lal, R (1985). Soil surface management in the tropics for intensive land use and high and sustained productivity. In: B.A. Stewart (ed), Advances in Soil Science. Vol. 5. 1985, 1-109

[33]. R. Lal. Methods and guidelines for assessing sustainable use of soil and water resources in the tropics. Ohio State Univ. Coumbus, OH, 1994, 78pp.

[34]. R. Lal. Soil quality and food security: the global perspective. In Lal, R (Ed.) Soil Quality and Soil Erosion. CRC Press, Boca Raton, FL, pp 3-16

[35]. J.R. Landon. BOOKER TROPICAL SOIL MANUAL. Longman Inc. New York. 1984, 450pp.

[36]. Y. Li, Q.U. Zhang, D.C.., Reicosky, M.J. Lindstrom L.Y.., Bai, and L. Li. Changes in SOC induced by tillage and water erosion on a steep cultivated hillslope in the Chinese Loess plateau from 1898-1994 and 1954-1998. J. of Geophysical Res. 2007,112

[37]. E.O. Mclean. Soil pH and lime requirement. Agron. 9. SSSA. Madison W.I. 1982, pp 199-224.

[38]. Mojiri, N. Emami and N. Ghafari. Effect of land use changes and hill slope position on soil qualities. African journal of agricultural research. Vol 6(5), 2011, 1114-1119.

[39]. M. Nanzyo, S. Shoji,and R. Dehigren. Physical characteristics of volcanic ash soils. In: Shoji, S., Nanzyo, M, Dehigren, R (eds). Volcanish Ash Soils. Genesis, properties and Utilization. Elsevier Sci. Publishers, B.V., Amsterdam. 1993, p.288

[40]. National Research Council, (1993). Soil and Water Quality: an Agenda for Agriculture. National Academy Press, Washinton, DC, 1993, 516pp.

[41]. D.W. Nelson, and C.E. Sommers. Total Carbon, Organic Carbon and Organic Matters, 1982, 539- 579. In: A.C. Page and C.A. Black (eds). Methods of Soil Analysis Part 2, $2^{\text {nd }}$ ed. Agron. Monogr. 9 ASA and SSA, Madison, W.I.

[42]. T.P. Ne'meth, P. Csatho' and A. Anton A (1998). Soil carbon dynamics in relation to cropping systems in principal ecoregions of Eastern Europe, with particular regard to Hungarian experiences. 1998, 255-283. In Lal et al (ed) Management of carbon sequestration in soil. Advances in Soil Science. CRC Press. New York

[43]. NEST. Nigerian Threatened Environment: A National Profile, Intec Publication, Ibadan, Nigeria. 1991

[44]. G.O. Oko-ibom, and J.E. Asiegbu. Growth and yield responses of rainy season field tomatoes to timing and splitting of fertilizer application. Journal of agriculture, food, environment and extension..5(1), 2006, 17-25.

[45]. T.A. Okusami,. R.H. Rust,and A.S.R Juo. Characterization and classification of some soil formed on post-cretaceous sediments in southern Nigeria. Soil Sci. 140, 1997, 110-119

[46]. S.R. Olsen, and L.E. Sommers, L.E (1982). Phosphorus. 1982, 403-434. In: Page et al (eds) Methods of Soil Analysis. Part 2. Agron 9. ASA, SSSA. Madison, W.I.

[47]. A.G. Ojanuga, and A.I. Awojuola,. Characteristics and classification of the soils of the Jos plateau, Nigeria. Nigerian Soil Science $10,1981,101-119$.

[48]. M.M. Pando, E. Jurado, M. Manzano, and E. Estrada E (2004). The influence of land use on desertification processes. J. Range Mgt. 57(3), 2004, 320-324

[49]. Rhoades, J.D (1982a). Cation exchange capacity. In: Page, A.L. (Ed.), Methods of Soil Analysis Part 2. 2nd Edition Agron. Monogr. 9. ASA, Madison, WI, pp. 149-157.

[50]. L. Rossiter. Lecture notes: land evaluation SCAS teaching series.1994. No. T94-1. FAO soils bulletin 32

[51]. SAS Institute, (2000). SAS Procedures Guide. Release 8 Edition, SAS, Cary, NC

[52]. M. Sanchez-Maranon, M., Sriano, G. Delgado, and R. Delgado. Soil quality in Mediterrenian mountains environment: Effects of land use change. Soil Sci. Soc. Amer.J 66, 2002, 948-958

[53]. K.S. Senthil, A.N.Kravchenko, G.P. Robertson. Soil carbon sequestration as a function of initial carbon content in different crop management systems of a long-term experiment. In: Abstracts $18^{\text {th }}$ World Congress of Soil Science, Inter. Union of Soil Science (IUSS), USA. SOM stabilization and carbon sequestration papers 2006, 139-144

[54]. D.L. Spark, DL (1995). Environmental soil chemistry. Academic press, Inc. San Diego, California.

[55]. K.L. Steenwerth, L.E. Jackson, F.J. Calderon, M.R. Stromberg, and K.M. Scow. Soil community composition and land use history in cultivated and grassland ecosystems of coastal California. Soil Bio \& Biochemistry 34(11), 2002, 1599-1611

[56]. C. Tisdell. Economic indicators to assess the sustainability of conservation farming projects: An evaluation. Agric. Ecosyst.Environ., 57, 1996, 117-31 
[57]. C. Tsui, Z.S. Chen, and C.F. Hsier. Relationships between soil properties and slope position in a lowland rain forest of southern Taiwan. Geoderma 123, 2004, 131-142

[58]. E.J. Udoh, IC. Idiong and G.N. Odok. Issues in sustainable and use and management in the rain forest belt of sub-Saharan Africa. J.Environ. Exten., 3, 2002, 16-20

[59]. URL: http://www.google.com/Online Nigeria (2003). Soil distribution along a toposequence.

[60]. University of Nigeria Meteorological Station, 2010.

[61]. Soil Survey Staff (1999). Soil Taxonomy: A basic System of Classification for making and interpreting soil surveys. N.R.C.S. USDA, Washinton D.C. $869 \mathrm{pp}$

[62]. J.R. Verde, M. Camps Arbestain, and F. Macias. Effect de las practicas agricolas sobre la estabilidad de los complejos organoalumicos en suelos andicos de Galicia. Edafologia 11, 2004, 319-328

[63]. World Bank. 1992. World Development Report. World Bank, Washington D.C 